遺伝性多発性外骨腫より二次性に 発生した軟骨肉腫の一例

熊本大学医学部整形外科（主任：北川敏夫教授）

久保田 健 治・森

熊本赤十字病院整形外科

松 永 保 英

\title{
Secondary Chondrosarcoma Derived from Hereditary Multiple Exostosis. \\ A Case Report
}

by

Kenji Kubota, Osamu Mori, Itsuo Honda and Masataka Harada

Department of Orthopaedic Surgery, Kumamoto

University Medical School, Kumamoto

Yasuhide Matsunaga

Department of Orthopaedic Surgery, Kumamoto

Redcross Hospital, Kumamoto

A 46-year-old man who had been diagnosed as hereditary multiple exostosis was admitted for treatment of large tumor of the left gluteal region.

$X$-ray revealed characteristic findings of chondrosarcoma and embolization of the superior gluteal artery was carried out before the operation. Extra-pelvic tumor was excised completely but intra-pelvic tumor was partially resected. Microscopic pathological diagnosis was well differentiated chondrosarcoma.

はじめに

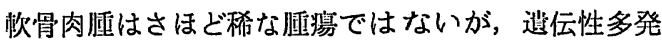
性外骨腫より二次性に発生したあのとなると，その報 告例は少ない，今回，我々は 46 才の男子の骨盤に巨 大なその一例を経験したので，若下の文献的考察を加 えて報告する.

$$
\text { 症 }
$$

例

\section{6才男子}

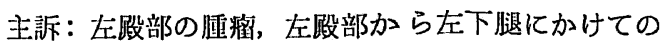
疼痛及びシビレ感.

既往歴：炤和 45 年，某医にて，多発生外骨腫の部 断のもとに，左大腿骨遗位端部，右陘骨近位端部，両 脛骨遠位端部の腫㕠切除術を受けている。

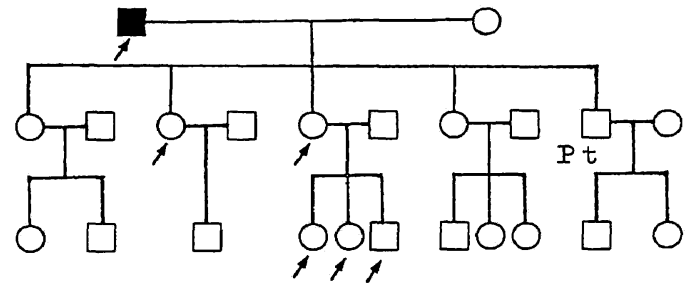

図1 家族歴：3 親等以内の親族 7 名に多発性外 骨腫の発生をみている。

家族歴：（図 1）のごとく，患者本人も含め，3 親 等以内の親族 7 名に多発生外骨腫の発生をみている.

現病歴：昭和 55 年 5 月頃, 左殿部の 腫瘤汇気付い たが，疼痛はなく，放置していた．同年 10 月頃より， 同部の疼痛が出現し, 左下腿外倒部にかけての放散痛 あ自覚した．その後, 腫瘤は増大傾向にあり,左前足部 
のシビレ感も出現する様になった，疼痛は，とくに夜 間仰卧位での就宸中に強かった.

また，昭和 57 年 5 月頃，同様の朠溜が左下腹部に あ存在することに気付き，これも以後增大傾向にあっ た.

昭和58年 5 月，上記症状のため近医起受晾し，当科 を紹介され，5月 30 日，手術目的にて当科に入院し た.

入院時所見：全身状態にはとくに異常は認めなかっ た. 左殿部には, $7 \times 20 \mathrm{~cm}$ と $12 \times 8 \mathrm{~cm}$ の 2 個の䤚 溜を認め，互いに㾤合していた，硬度は弾性㳄，表而 は平滑，辺縁不明膫で，可政性はなかった。怪度の局 所熱感も認められた。 また，左上前腸骨料内側の左下 腹部にも， $8 \times 10 \mathrm{~cm}$ の同様の腫熘を蚛知した。

下肢の神経学的検查では, 樑部涏反射には異常は認

められなかったが，知觉椧位で左：足背部の怪度の知觉 䤞唯，管力検查で，左股闺節の仪展及び外忶管力の低 下，左足関節背屁筋力の低下が認められた。

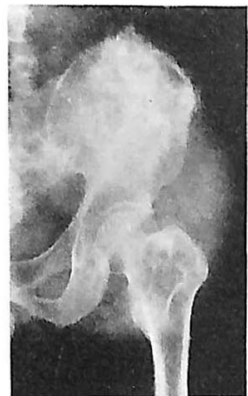

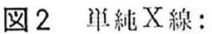
左腸骨部化 買常陰影を 羿める。

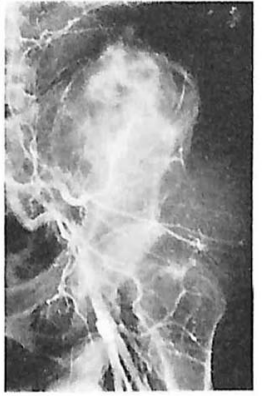

図4 InIl管造影：上：

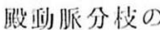
压排仲展が篦 明である。
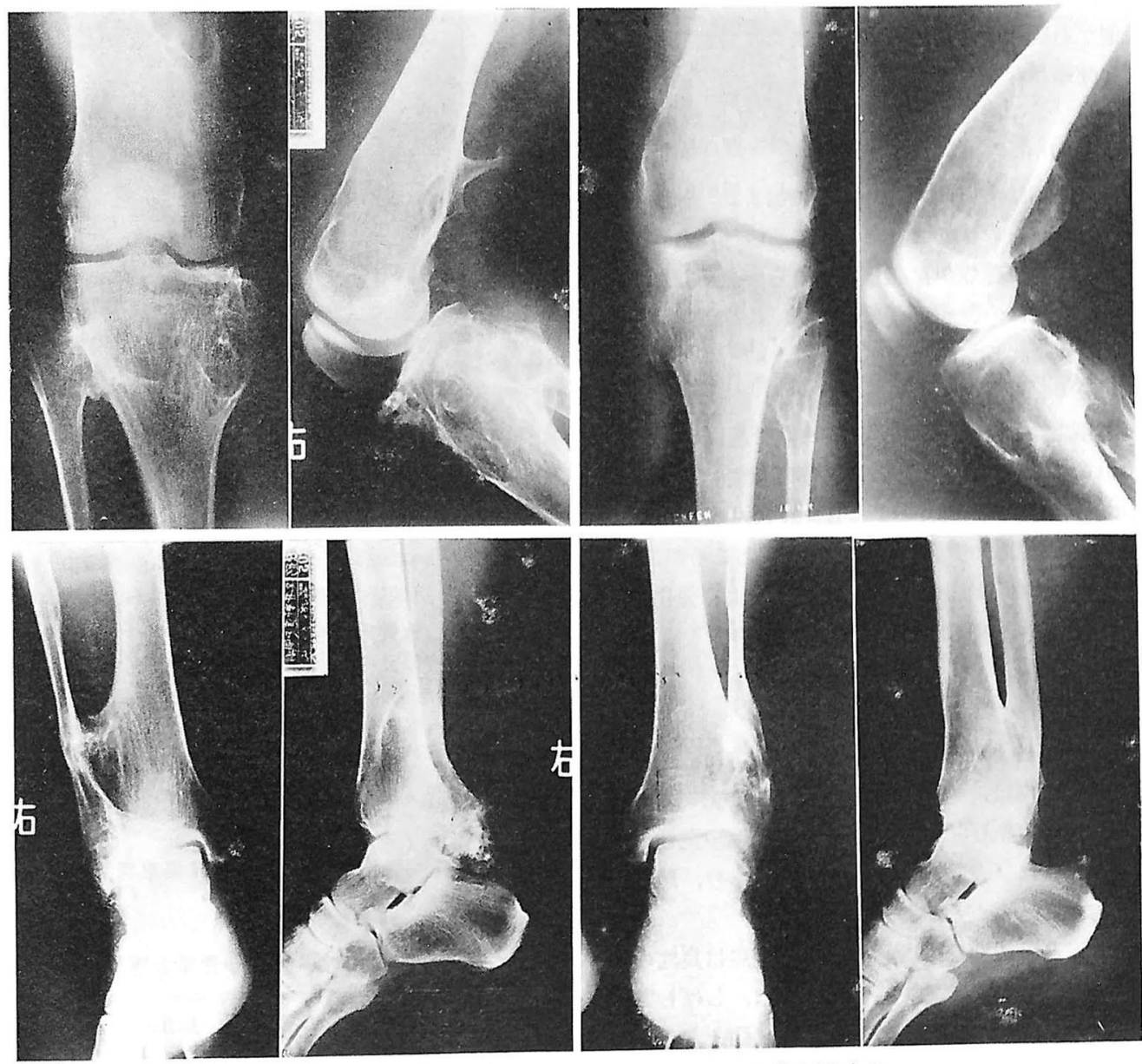

図 3

単純 $\mathrm{X}$ 線：多発性外骨腫及びその切除端を認める。 
一般検查成績：へモグラムに異常は認めずまた， IIIl沈 1 時間值! $3 \mathrm{~mm}, 2$ 時間佰 $5 \mathrm{~mm}, \mathrm{CRP}(-)$ で あった．烅液生:化では，血咔総タンパク $6.3 \mathrm{~g} / \mathrm{dl}$, アルブミン $3.7 \mathrm{~g} / \mathrm{dl}$ の低下, IIIl汿筷 $195 \mu \mathrm{g} / \mathrm{dl}$, ALP $117 \mathrm{u} / \mathrm{dl}, r$-GTP 76u/dl の上昇が認められた. ALP isozyme は, 2 分西 $50 \%, 3$ 分画 $46 \%$ \%゙っ た.

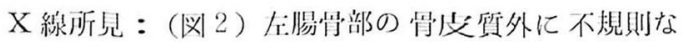

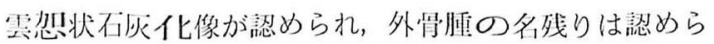
れなかったが, 雨滕, 雨足関䬣部（図３）には，多発 性の外剈腷及びその切除端が認められた。

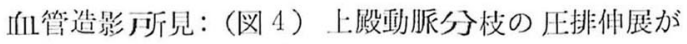
著川であり，一部 hypervascular な部分もあるが， 不規则な不扊化を示寸部分は, むしろ hypovascular であった。

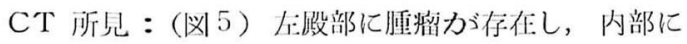
不規則な不火化像が惩められた。また，骨盤腔内にむ 巨大な怔渻が存在していた。

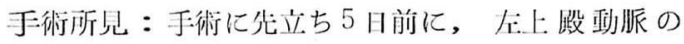
embolizati on を施行した.

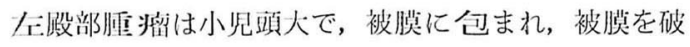
ると白いクリーム状であった。 その遥位部にも 3 個の 手举大の同様の腫楅が存在し，とれらを全摘した．腸

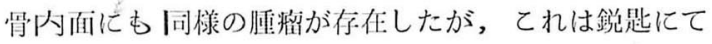
可能な限り搔爬した。術中出血量は, 約 $540 \mathrm{ml}$ であ った。

病理組織学所見：（图 6 A）成染㳄骨基質をもった chondrocyte の增生から成る腫陽で收胃は分葉状增 生を示していた（図6B) chondrocyteには, 2 核のものや，部分的な密な增殖を示すところがあり， 不灰化果が浔められる部分も存在した．上く分化した 㳄骨肉㮌と考无られた。

$$
\text { 考察 }
$$

諸家の報告によれば，饮骨肉䤚全体に占める二次性 㳄骨肉嗹の比率は，表 1)のでとくであり，おおよ そ $10 \%$ 前後之考元ら机る. また，选伝性多発性外骨

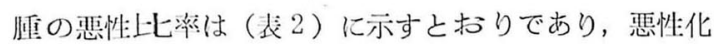
は比較的稀であることがわかる.

軟骨肉朠との鑑別を最も必要とする瓷患は良性の軟

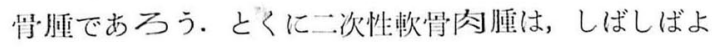
く分化した組織像を呈するので，一居問題となること が多い，組織兴的恶性を寺す所見としては，・㤥の買
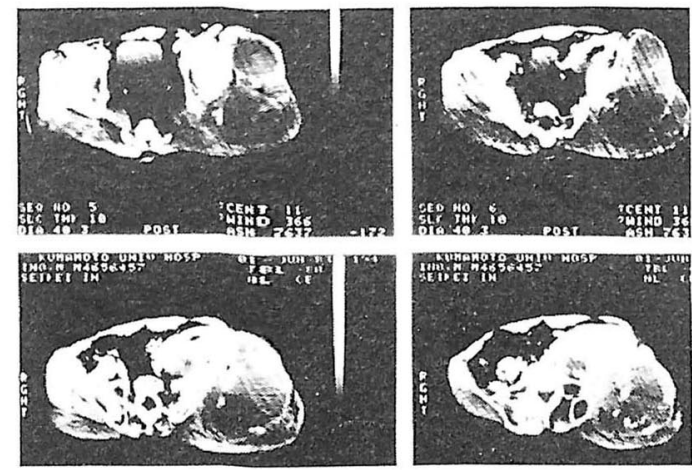

図５ＣＴ：左三踧部及び骨盤腔内に巨大な胜 瘤を想める。

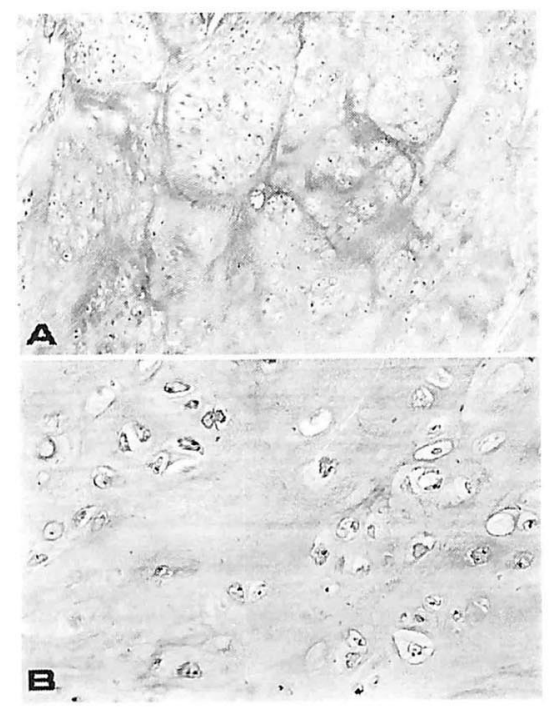

図6 病理組織：A：H. E. $\times 40$

B : H. E. $\times 200$

表 1 㳄骨肉肥全体飞占好る二次性㳄骨肉堙 の比摔

\begin{tabular}{|c|c|c|c|}
\hline 約 $50 \%$ & & Geschickter & (1949) \\
\hline $11.1 \%$ & $(32 / 288)$ & Henderson & (1963) \\
\hline $5.0 \%$ & $(1 / 20)$ & Phelan & (1964) \\
\hline$=7.9 \%$ & $(12 / 151)$ & McKenna & (1966) \\
\hline $4.5 \%$ & $(7 / 157)$ & Bom & (1966) \\
\hline $13.3 \%$ & $(8 / 60)$ & 阿 & (1967) \\
\hline $7.8 \%$ & $(15 / 193)$ & (1) & 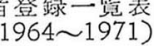 \\
\hline
\end{tabular}

表 2 造伝性多発性外骨腫の悪性化率

\begin{tabular}{rlll}
\hline \hline $10.7 \%$ & $(3 / 28)$ & Jaffe & $(1958)$ \\
$2.2 \%$ & $(2 / 91)$ & 阿 部 & $(1967)$
\end{tabular}


型性・腫大， - 核分裂像，・同一 lacuna 内に 2 個以 上の細胞の存在, ・多核巨細胞の出見, ・bizarre cell の出現, ・石灰沈着などがある. 我々は, O'Neal と Ackerman の悪性度分類に基づき，低悪性度 との組織所見を得た. また, Evans の分類では, Grade I であった.しかし，診断に際しては，病理 組織学所見もさることながら，X線所見，臨床所見及 び経過が十分に加味されなければならない。

手術中の出血量が約 $540 \mathrm{mI}$ と, この種の手術にし ては比較的少量であったが，乙れは，手術前に行なっ た embolization の効果であると思われる.

$$
\text { ま と め }
$$

我々は，46才男子の腸骨に，选伝性多発性外骨腫 より二次性に発生した軟骨肉腫の一例を 経験したの で，若干の文献的考察を加え，報告した.

\section{文献}

1) 阿部俊光 - 他：2 次性㳄骨肉腄について. 整形 外科, 18: 1079-1087, 1967.

2) Bom, J. B. et al.: Radiological atlas of bone tumors I. Mouton Co., Hague, 1966.

3) Evans, H. L. et al.: Prognostic factors in chondrosarcoma of bone. Cancer, 40: 818-831, 1977.

4) Geschickter, C. F. et al.: Tumors of bone, ed. 3. J. B. Lippincott Co., Philadelphia, 1949.

5）林: 靖邦 - 他：軟骨性腫湢の悪性度の判定につ いての研究 (第 1 報)。日整会誌, 57：607-616, 1983.

6) Henderson, E. D. et al.: Chondrosarcoma of bone-a study of two handred and eighty-eight cases. J. Bone Joint Surg., 45-A : 1450-1453, 1963.

7) Jaffe, H. L.: Tumors and Tumorous Conditions of the Bones \& Joints. Lea and Febiger, Philadelphia, 1960.

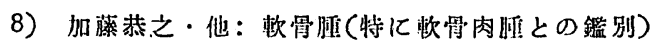
について. 臨整外, 5: 801-806, 1970.

9) McKenna, R. J. et al.: Sarcoma of the osteogenic series (Osteosarcoma, fibrosarcoma, chondrosarcoma, parosteal osteogenic sarcoma, and sarcomata arising in abnormal bone). J. Bone Joint Surg., 48-A : 1-26, 1966.

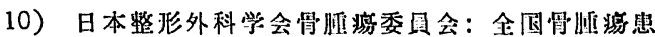
者一管表。国立がんセンター，来京， 1980 .

11) O'Neal, L. W., and AcKerman, L. V.: Chondrosarcoma of bone. Cancer, 5: 551577, 1952.

12) Phelan, J. T. et al.: Chondrosarcoma of bone. Surg., Gynec., and Obstet., 119: 4246, 1964.

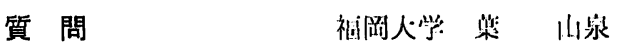

ての症例は最初加ら根治手術が不可能と考えられて 手術されたのか.

解 答热本大学 久保惟健治 左殿部の腄瘤の摘出を腎者は強く希望し，骨艁腔内

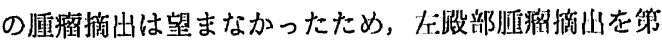
一に考え手術しました。

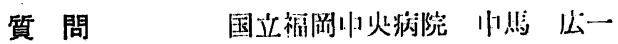
最近, Digital Angrography が行なわれている. また化学療法前後に，能肉雸では血管造影を行なって いる, Digital Angrography の精度はいかがでしょ うか.

解 答 熊本大学 原阴 正孝

デジタルアンギオの解像力は $0.5 \mathrm{~m} / \mathrm{m}$ といわれ, fine な所見は従来の血管造影の方が得られる.Tumor stain のような全体像はデジタルの方が僛れて いる. 